\title{
ANALISIS HUBUNGAN MODAL INTELECTUAL (INTELLECTUAL CAPITAL) TERHADAP KINERJA KEUANGAN BUM DESA DI KECAMATAN BANTAN KABUPATEN BENGKALIS
}

\section{Analysis of The Relationship of Intellectual Capital to the Financial Performance of Bumdesa in Bantan District, Bengkalis Regency}

\author{
Ririn Agustiawati, Ahmad Rifai, Kausar \\ Jurusan Agribisnis, Fakultas Pertanian, Universitas Riau \\ Email: ririnagustiawati468@gmail.com, ahmadrifaihs@gmail.com, kausar_ur@yahoo.co.id
}

[Diterima: November 2021; Disetujui: Desember 2021]

\begin{abstract}
The existence of BUM Desa was formed as an expectation to be able for encouraging the dynamics of economic life in rural areas with good financial performance and competitiveness with the management of intellectual capital, human resources, and innovative collaboration. This study aims to identify the existence of intellectual capital and to analyze its relationship with the financial performance of BUM Desa in Bantan District. The method used in this study is a survey method by interviewing 27 respondents. The results indicate that intellectual capital and financial performance had a very close and harmonious relationship. In improving the performance of BUM Desa in Bantan District, the most important form of intellectual capital was relational capital, namely the attitude of BUM Desa management and leaders who help each other to develop business units. Relational capital was formed by the dimension of relationships with customers who accept criticism and suggestions from BUM Desa customers. Meanwhile, Human capital was formed by the dimensions of the attitude of the BUM Desa management in carrying out their duties. BUM Desa which has higher intellectual capital had better financial performance, so the development of Intellectual Capital as a tangible asset needs to be developed in the future to improve the financial performance of BUM Desa.
\end{abstract}

Keywords: Intellectual Capital, Intangible Asset, Financial Performance, BUM Desa.

\begin{abstract}
ABSTRAK
Keberadaan BUM Desa dibentuk sebagai harapkan agar mampu mendorong dinamisasi kehidupan ekonomi di pedesaan dengan kinerja keuangan yang baik dan berdaya saing dengan pengelolaan Intellectual Capital, SDM dan kerjasama yang inovatif.Penelitian ini bertujuan untuk mengidentifikasi keberadaan Intellectual Capital dan menganalisis hubungannya dengan kinerja keuangan BUM Desa di Kecamatan Bantan.Metode yang digunakan dalam penelitian ini adalah metode survei mewancarai 27 responden.Hasil penelitian ini menunjukan bahwa modal intelectual dan kinerja keuangan memiliki hubungan yang sangat terikat dan selaras.Peningkatan kinerja pada BUM Desa di Kecamatan Bantan,dan pembentuk Intellectual Capital yang paling penting adalahrelational capital, yaitu sikap pengurus dan pimpinan BUM Desa yang saling membantu satu sama lain untuk mengembangkan unit usaha. Relational Capital dibentuk oleh dimensi relasi dengan pelanggan yang menerima kritik dan saran pelanggan BUM Desa. Sedangkan Human capital dibentuk oleh dimensi sikap pengurus BUM Desa dalam melaksanakan tugasnya.BUM Desa yang memiliki modal intelektual lebih tinggi memiliki kinerja keuangan yang lebih baik, sehingga pengembangan Intellectual Capital sebagaitangible asset perlu dikembangkan dimasa mendatang untuk meningkatkan kinerja keuangan BUM Desa.
\end{abstract}

Kata kunci:Modal Intelektual, Aset Tak Berwujud, Kinerja Keuangan, BUM Desa.

\section{PENDAHULIAN}

Desa sebagai pemerintahan yang langsung bersentuhan dengan masyarakat menjadi fokus utama dalam pembangunan pemerintah, hal ini dikarenakan sebagian besar wilayah Indonesia ada di perdesaan. Desa dapat mendirikan badan usaha milik desa sesuai dengan kebutuhan dan potensi desa (UndangUndang Nomor 32 Tahun 2004 tentang 
Pemerintahan Daerah, Pasal 213 ayat [1]). Substansi Undang-Undang ini menegaskan tentang janji pemenuhan permintaan dalam konteks pembangunan tingkat desa. Badan Usaha Milik Desa (BUM Desa) merupakan lembaga usaha desa yang dikelola oleh masyarakat dan pemerintahan desa dalam upaya memperkuat perekonomian desa dan dibentuk berdasarkan kebutuhan dan potensi desa.

Keberadaan BUM Desa dibentuk sebagai harapkan agar mampu mendorong dinamisasi kehidupan ekonomi di pedesaan. Peran pemerintah desa adalah membangun relasi dengan masyarakat untuk mewujudkan pemenuhan standar pelayanan minimal (SPM), sebagai bagian dari upaya pengembangan komunitas desa yang lebih berdaya serta sebagai salah satu penopang atau penguat ekonomi desa yang merupakan bagian integral dari Negara Republik Indonesia.

Peraturan Menteri Dalam Negeri No 04 tahun 2007 menjelaskan kekayaan desa adalah barang milik desa yang berasal dari kekayaan asli desa, dibeli atau diperoleh atas beban Anggaran Pendapatan dan Belanja Desa atau perolehan hak lainnya yang sah. Kekayaan desa mengerucut kepada pengertian kebendaan yang dikelola oleh pemerintah desa. Pengelolaan kekayaan desa harus berdaya guna dan berhasil guna untuk meningkatkan pendapatan desa.namun kekayaan desa atau aset desa sendiri selama ini belum terkelola dan terolah secara maksimal bagi program peningkatan kesejahteraan masyarakat desa.

Kondisi BUM Desa di Kabupaten Bengkalis dalam pelaksanaannya sudah berjalan dengan baik, BUM Desa sebagai wadah usaha bagi desa, memiliki semangat kemandirian, kebersamaan dan kegotongroyongan antara Pemerintah Desa dan masyarakat untuk mengembangkan asset-aset lokal dalam memberikan pelayanan dan meningkatkan pendapatan ekonomi masyarakat dan desa.

Pada akhir tahun setiap desa melaksanakan musyawarah desa yang salah satu agendanya yaitu membahas laporan pertanggung jawaban BUM Desa selama 1 periode atau 1 tahun kepengurusan, dalam musyawarah ini dibahas mengenai asal modal BUM Desa, program kerja yang telah dilaksanakan, permasalahan yang dihadapi, serta laporan keuangan selama 1 tahun kepengurusan BUM Desa. Laporan keuangan yang dihasilkan masih bersifat akuntansi tradisional, dan hanya memaparkan laporan hasil dari penggunaan tangible asset. Belum adanya perhitungan dan pengukuran terhadap asset tidak berwujud (intangible asset) tersebut membuat penulis tertarik untuk melakukan penelitian tentang "Analisis Hubungan Modal Intellectual Capital Terhadap Kinerja Keuangan BUM DESA Kecamatan Bantan Kabupaten Bengkalis".

\section{METODE PENELITIAN}

Penelitian ini akan dilaksanakan di 3 Desa Kecamatan Bantan, Kabupaten Bengkalis, Provinsi Riau, yaitu: Desa Jangkang, Desa Kualu Pasiran dan Desa Resam, dengan pertimbangan bahwa BUM Desa yang dipilih adalah yang aktif di Kecamatan Bantan, Kabupaten Bengkalis. Adapun responden dalam penelitian ini adalah Kepala Desa, Direktur BUM Desa, Sekretaris, Bendahara, Kepala Unit, anggota dan pengawas sebanyak 27.

Analisis yang digunakan dalam penelitian ini adalah model intelektual yang terdapat pada BUMDesa dengan pembentuk modal manusia (human capital), modal structural (struktur capital), modal relasi (relational capital). Kemudian untuk analisis kinerja keuangan BUMDesa proksi yaitu ROA, ROE, dan BOPO.

Analisis hubugan modal intelektual terhadap kinerja BUMDesa dilihat dari kecenderungan pembentukan modal intellectual dan kinerja keuangan masing-masing BUMDesa yang dijelaskan secara deskriptif.

\section{HASIL DAN PEMBAHASAN}

Pada konsep human capital organisasi memperlakukan orang bukan sebagai faktor biaya, melainkan sebagai asset (Parulian, 2008). Artinya, organisasi menganggap setiap biaya yang dikeluarkan untuk pengembangan sumber daya manusia adalah investasi, yang pada akhirnya biaya-biaya tersebut akan memberikan hasil pada organisasi.

Hasil penelitian menunjukkan bahwa dimensi sikap karyawan BUMDesa dalam melaksanakan tugas dan dimensi sikap direktur terhadap karyawan merupakan pembentuk utama modal manusia pengurus BUMDesa di Kecamatan Bantan. Hasil ini sama dengan yang ditemukan Ayub (2020) yang menunjukan bahwa pembentuk dimensi modal manusia adalah kreatifitas karyawan BUMDesa 
sedangkan Mira (2020) menemukan relational capital yang menunjukan sikap pengurus dan pimpinan BUM Desa yang saling membantu satu sama lain, mempunyai kerjasama yang baik dengan badan usaha untuk mengembangkan unit usaha dari BUM Desa. Hal ini menunjukkan bahwa sikap karyawan merupakan hal penting untuk meningkatkan kinerja BUM Desa.Secara lengkap pembentuk modal manusia pada BUMDesa di Kecamatan Bantan disajikan pada Tabel 1 berikut.

Tabel 1 Peran Modal Manusia dan Unsur Pembentuk Modal Manusia Pengurus BUMDesa di Kecamatan Bantan

\begin{tabular}{|c|c|c|c|c|c|}
\hline No & Dimensi & Indikator Modal Manusia & $\begin{array}{l}\text { Rata- } \\
\text { rata }\end{array}$ & Skor & Kategori \\
\hline \multirow{4}{*}{1} & \multirow{4}{*}{$\begin{array}{l}\text { Kompetensi } \\
\text { pengurus BUM } \\
\text { Desa dalam } \\
\text { menjalankan } \\
\text { tugas }\end{array}$} & 1. Berpendidikan tinggi & \multirow{4}{*}{3,56} & 3,74 & Berperan \\
\hline & & 2. Mendapatkan pelatihan & & 3 & Berperan \\
\hline & & 3. Pelatihan disesuaikan dengan jabatan & & 3,51 & Berperan \\
\hline & & $\begin{array}{l}\text { 4. Pendidikan mempengaruhi terhadap } \\
\text { kualitas kerja }\end{array}$ & & 4 & Berperan \\
\hline \multirow{4}{*}{2} & \multirow{4}{*}{$\begin{array}{l}\text { Sikap Direktur } \\
\text { terhadap } \\
\text { karyawan }\end{array}$} & 1. Karyawan selalu bahagia & \multirow{4}{*}{4,19} & 4,29 & Sangat berperan \\
\hline & & 2. Kepuasan pada karyawan & & 3,92 & Berperan \\
\hline & & 3. Membantu dalam masalah kantor & & 4,40 & Sangat berperan \\
\hline & & 4. Harapan kualitas direktur & & 4,18 & Sangat berperan \\
\hline \multirow{3}{*}{3} & \multirow{3}{*}{$\begin{array}{l}\text { Sikap Karyawan } \\
\text { dalam } \\
\text { melaksanakan } \\
\text { tugas }\end{array}$} & 1. Senang bekerja di BUM Desa & & 4,14 & Sangat berperan \\
\hline & & 2. Memberikan bantuan ketika dibutuhkan & 4,26 & 4,25 & Sangat berperan \\
\hline & & 3. Diberikan pekerjaan khusus & & 4,40 & Sangat berperan \\
\hline \multirow{4}{*}{4} & \multirow{3}{*}{$\begin{array}{l}\text { Kreatifitas } \\
\text { karyawan dalam } \\
\text { menjalankan } \\
\text { tugas }\end{array}$} & 1. Karyawan kreatif dan cerdas & \multirow{3}{*}{3,99} & 4,14 & Sangat berperan \\
\hline & & 2. Karyawan memiliki ide baru & & 4,03 & Berperan \\
\hline & & 3. Karyawan termotivasi memberikan ide & & 3,81 & Berperan \\
\hline & & Rata-rata & & 3,96 & Berperan \\
\hline
\end{tabular}

Hasil penelitian menunjukan bahwa pembentukan utama modal manusia BUMDesa di Kecamatan Bantan adalah dimensi sikap direktur BUMDesa terhadap karyawan dan dimensi sikap karyawan BUMDesa dalam melaksanakan tugas.Dimensi sikap karyawan dalam melaksanakan tugas dibentuk oleh indikator-indikator dengan hasil sangat berperan pada indikator karyawan BUMDesa senang bekerja di BUMDesa. Indikator memberikan bantuan ketika dibutuhkan dan indikator diberikan pekerjaan khusus. Kemudian dimensi sikap direktur BUMDesa terhadap karyawan dibentuk oleh indikator dengan hasil sangat berperan pada indikator karyawan selalu bahagia, indikator membantu masalah kantor dan indikator harapan kualitas direktur. Sedangkan indikator kepuasan kepada karyawan masih kategori berperan. Dimensi kreatifitas karyawan dalam menjalankan tugas dibentuk oleh indikator karyawan kreatif dan cerdas dengan kategori sangat berperan sedangkan indikator karyawan memiliki ide baru dan karyawan termotivasi memberikan ide masih pada kategori berperan. Kemudian, dimensi kompetensi pengurus BUMDesa dalam menjalankan tugas dibentuk oleh semua indikator dengan kategori berperan, yaitu berpendidikan tinggi, mendapat pelatihan, pelatihan disesuaikan dengan jabatan dan pendidikan mempengaruhi kualitas kerja.

Hasil penelitian pada Tabel 2 menujukkan bahwa variabel modal relasi yang memiliki indikator relasi dengan pelanggan yang tinggi yaitu kritik dan saran dari pelanggan dengan skor 4,48 dan termasuk kategori sangat berperan, menjadi satu hal peningkatan dan perbaharuan terhadap suatu unit usaha untuk bisa memberikan yang terbaik bagi masyarakat atau pelanggan BUM Desa. Paling rendah dari relasi terhadap pelanggan adalah data pelanggan yang harus selalu diperbarui dengan skor 3,70 dengan kategori berperan untuk selalu memperbarui data agar memiliki 
administrasi yang baik serta data yang rapi. Relasi dengan karyawan yang memiliki indikator paling tinggi adalah kemampuan bertambah melalui interaksi dengan skor 3,96 dengan kategori berperan. Interkasi dari penguru dan pelanggan menjadi hal untuk menjalin sebuah komunikasi yang baik agar tercipta kenyamanan bagi pelanggan untuk terus mempercayai unit usaha yang ada di BUM
Desa. Dan yang paling rendah dengan indikator mengalami peningkatan rentan waktu untuk pelanggan yang memiliki skor 3,51 dengan kategori berperan, untuk menjadi catatan meningkatkan jumlah pelanggan dengan targetan yang disediakan atau sudah direncanakan sehingga usaha-usaha BUM Desa dapat meningkat dengan baik.

Tabel 2 Peran Modal Relasi dan Unsur Pembentuk Modal Relasi Pengurus BUM Desa di Kecamatan Bantan

\begin{tabular}{|c|c|c|c|c|c|}
\hline No & Dimensi & Indikator Modal Relasi & $\begin{array}{c}\text { Rata- } \\
\text { rata }\end{array}$ & Skor & Kategori \\
\hline \multirow{9}{*}{1} & \multirow{9}{*}{$\begin{array}{l}\text { Relasi } \\
\text { Pengurus } \\
\text { BUM Desa } \\
\text { dengan } \\
\text { Pelanggan }\end{array}$} & 1. $\quad$ Data pelanggan selalu diperbarui & \multirow{9}{*}{4,13} & 3,70 & berperan \\
\hline & & $\begin{array}{l}\text { 2. BUM Desa secara kontinu menemui } \\
\text { pelanggan }\end{array}$ & & 3,74 & berperan \\
\hline & & 3. Kritik dan saran dari pelanggan & & 4,48 & sangat berperan \\
\hline & & $\begin{array}{l}\text { 4. Kritik dan saran dari pelanggan } \\
\text { diberitahu kesemua karyawan }\end{array}$ & & 4,40 & sangat berperan \\
\hline & & $\begin{array}{l}\text { 5. Pelanggan selalu mendapatkan } \\
\text { kebutuhan yang diperlukan }\end{array}$ & & 4,03 & berperan \\
\hline & & $\begin{array}{l}\text { 6. Penyimpanan data pribadi pelanggan } \\
\text { tersimpan dengan rahasia }\end{array}$ & & 4,44 & sangat berperan \\
\hline & & 7. Memberikan pelayanan yang baik & & 4,29 & sangat berperan \\
\hline & & $\begin{array}{l}\text { 8. } \begin{array}{l}\text { Memberikan kemudahan terhadap } \\
\text { pelanggan }\end{array} \\
\end{array}$ & & 4,14 & sangat berperan \\
\hline & & $\begin{array}{l}\text { 9. Menyakinkan pelanggan terhadap } \\
\text { BUM Desa }\end{array}$ & & 4 & berperan \\
\hline No & Dimensi & Indikator Modal Relasi & $\begin{array}{l}\text { Rata- } \\
\text { rata }\end{array}$ & Skor & Kategori \\
\hline \multirow{6}{*}{2} & \multirow{5}{*}{$\begin{array}{l}\text { Relasi } \\
\text { sesama } \\
\text { Karyawan }\end{array}$} & $\begin{array}{l}\text { 1. Kemampuan bertambah melalui } \\
\text { interaksi }\end{array}$ & \multirow{5}{*}{4,032} & 3,96 & berperan \\
\hline & & $\begin{array}{l}\text { 2. Karyawan mampu bekerjasama dengan } \\
\text { karyawan lain }\end{array}$ & & 4,18 & sangat berperan \\
\hline & & $\begin{array}{l}\text { 3. Cara karyawan memberikan pelayanan } \\
\text { terhadap pelanggan }\end{array}$ & & 4,40 & sangat berperan \\
\hline & & $\begin{array}{l}\text { 4. } \begin{array}{l}\text { Mengalami peningkatan jumlah } \\
\text { pelanggan }\end{array} \\
\text { plan }\end{array}$ & & 4,11 & sangat berperan \\
\hline & & 5. Mengalami peningkatan rentan waktu & & 3,51 & sangat berperan \\
\hline & \multicolumn{3}{|c|}{ Rata-rata } & 4,09 & berperan \\
\hline
\end{tabular}

Structural Capital merupakan sarana prasarana pendukung kinerja pengurus. Modal struktural merupakan penghubung human capital menjadi modal intelektual. Maksudnya meskipun pengurus memiliki intelektual yang tinggi, namun kalau tidak didukung oleh sarana yang memadai untuk mengaplikasikan inovasi mereka, maka kemampuan tersebut tidak akan menghasilkan modal intelektual. Nilai modal struktural pengurus BUM Desa di Kecamatan Bantan pada Tabel 3 berikut.
Berdasarkan Tabel 3 dapat dilihat modal struktural inovasi yang paling tinggi dengan indikator pengetahuan pengurus selama di BUM Desa meningkat dengan skor 4,18 dalam kategori berperan, menjadikan pengurus selau memiliki pengetahuan baru melalui interaksi dan inovasi-inovasi yang baru diberikan. Dan yang paling rendah dengan indikator pengembangan inovasi yang baru memiliki skor 3,81 dalam kategori berperan menyebabkan kurangnya penyediaan atau fasilitas yang memadai disuatu kantor BUM Desa. 
Tabel 3 Peran Modal Struktural dan Unsur Pembentuk Modal Struktural Pengurus BUM Desa di Kecamatan Bantan

\begin{tabular}{|c|c|c|c|c|c|}
\hline No & Dimensi & Indikator Modal Struktural & Rata-rata & Skor & Kategori \\
\hline 1 & $\begin{array}{l}\text { Kemampuan } \\
\text { Karyawan } \\
\text { dalam } \\
\text { melakukan } \\
\text { Inovasi }\end{array}$ & $\begin{array}{l}\text { 1. Suasana BUM Desa sangat nyaman } \\
\text { 2. Pengetahuan selama di BUM Desa } \\
\text { meningkat } \\
\text { 3. Pengembangan inovasi yang baru } \\
\text { 4. Inovasi yang didukung oleh BUM } \\
\text { Desa }\end{array}$ & 4,11 & 4,18 & $\begin{array}{l}\text { Sangat Berperan } \\
\text { Berperan } \\
\text { Berperan }\end{array}$ \\
\hline 2 & $\begin{array}{l}\text { Proses } \\
\text { Perkembangan } \\
\text { BUM Desa }\end{array}$ & $\begin{array}{l}\text { 1. Terdapat informasi dalam struktur } \\
\text { dan sistem } \\
\text { 2. Informasi dapat diakses kapanpun } \\
\text { 3. Terdapat pengembangan kreativitas } \\
\text { dalam bekerja } \\
\text { 4. Kerjasama BUM Desa } \\
\text { 5. Model transaksi di BUM Desa }\end{array}$ & 3,83 & $\begin{array}{l}3,9 \\
4,31 \\
3,22\end{array}$ & $\begin{array}{l}\text { Cukup Berperan } \\
\text { Berperan } \\
\text { Sangat Berperan } \\
\text { Cukup Berperan }\end{array}$ \\
\hline 3 & $\begin{array}{l}\text { Teknologi } \\
\text { Informasi yang } \\
\text { digunakan } \\
\text { BUM Desa }\end{array}$ & $\begin{array}{l}\text { 1. BUM Desa menggunakan computer } \\
\text { 2. Promosi melalui media } \\
\text { 3. Teknologi berkontribusi dalam } \\
\text { pelayanan }\end{array}$ & 3,95 & $\begin{array}{c}4,5 \\
3,28 \\
4,09\end{array}$ & $\begin{array}{l}\text { Sangat Berperan } \\
\text { Cukup Berperan } \\
\text { Berperan }\end{array}$ \\
\hline 4 & $\begin{array}{l}\text { Budaya yang } \\
\text { diterapkan } \\
\text { BUM Desa }\end{array}$ & $\begin{array}{l}\text { 1. Sistem dan prosedur mendukung } \\
\text { inovasi } \\
\text { 2. Karyawan BUM Desa sangat } \\
\text { berdaya } \\
\text { 3. Karyawan memiliki inisiatif }\end{array}$ & 4,29 & 4,13 & $\begin{array}{l}\text { Berperan } \\
\text { Sangat Berperan } \\
\text { Sangat Berperan }\end{array}$ \\
\hline & & Rata-rata & & 4,04 & Berperan \\
\hline
\end{tabular}

Sumber :Data Olahan 2020

Modal structural proses dengan indikator yang paling tinggi yaitu 4,50 dalam kategori sangat berperan kerjasama BUM Desa menjadi salah satu link untuk meningkatkan kemampuan hubungan pengurus dan toko-toko atau perusahaan yang membantu. Model relasi dengan teknologi informasi yang paling rendah adalah indikator penggunaan media dengan skor 3,28 dalam kategori cukup berperan. Kurangnya penggunaan media juga menjadi faktor penghambat berkembangnya BUM Desa, dengan perlunya BUM Desa mempelajari cara promosi, penggunaan media menjadi penting untuk meningkatkan pelanggan BUM Desa. Dan modal struktural budaya dengan indikator pengurus BUM Desa sangat berdaya memiliki skor paling tinggi yaitu 4,54 dalam kategori sangat berperan. Dengan memiliki pengurus sangat berdaya terutama melalui pelatihanpelatihan yang di ikuti oleh pengurus atau direktur dengan membagikan ilmu tersebut kepada pengurus dan menerapkannya ke BUM Desa menjadi salah satu alternatif agar BUM Desa dapat berkembang dengan baik.

$$
\text { Modal Intellectual merupakan }
$$

pengalaman terapan, teknologi organisasional, hubungan pelanggan, dan keahlian yang dapat menciptakan keunggulan kompetitif BUM Desa untuk terus meningkatkan kinerja serta kerjasama baik internal pengurus maupun external pengurus BUM Desa. Modal intelectual yang dimiliki oleh pengurus BUM Desa Kecamatan Bantan dapat dilihat pada Tabel 4 berikut.

Berdasarkan Tabel 4 dapat dilihat bahwa BUM Desa yang memiliki skor modal manusia (Human Capital) tertinggi ada pada BUM Desa Jangkang Sejahtera dengan skor 4,41 selanjutnya BUM Desa pasir bulan dengan skor 3,98, dan BUM Desa mulya jaya abadi dengan skor 3,16. Human capital menjadi salah satu faktor penting dengan fokus utama adalah pada pengurus bagaimana pendidikan, kualifikasi kejuruan, yang berhubungan dengan pekerjaan pengetahuan, kompetensi yang berhubungan dengan pekerjaan, semangat kewirausahaan, inovasi, kemampuan proaktif dan reaktif, dan kemampuan beradaptasi. Dari 3 BUM Desa tersebut yang memiliki modal manusia (Human Capital) lebih baik adalah BUM Desa Jangkang Sejahtera dari BUM Desa lainnya. 
Tabel 4 Tingkat dan Variabel Pembentuk Modal Intelektual Pengurus BUM Desa di Kecamatan Bantan.

\begin{tabular}{lcccc}
\hline \multicolumn{1}{c}{ Nama BUM Desa } & Human Capital & Relational Capital Structural Capital & modal intellectual \\
\hline Jangkang Sejahtera & 4,41 & 4,48 & 4,43 & 4,44 \\
Pasir Bulan & 3,98 & 4,09 & 3,65 & 3,90 \\
Mulya Jaya Abadi & 3,16 & 3,58 & 3,05 & 3,26 \\
\hline
\end{tabular}

Sumber : Data Olahan 2020

Relational capital yang tertinggi dapat dilihat yaitu BUM Desa jangkang sejahtera yang memiliki skor 4,48, lalu BUM Desa pasir bulan dengan skor 4,09, dan terakhir BUM Desa mulya jaya abadi dengan skor 3,58. Relational capital menjadikan BUM Desa Jangkang Sejahtera memiliki hubungan yang baik dengan pengurus dan pelanggannya. Sehingga modal Relasi (Relational capital) sesuai dengan pernyataan menurut Ambar, 2004 bahwa melalui pengetahuan karyawan yang diproses dengan modal struktural yang akhirnya menghasilkan hubungan yang baik dengan pihak luar. Hubungan komunikasi menjadi hal penting yang perlu ditingkatkan untuk membangun kepercayaan dan kerjasama.

Structural capital (modal struktur) yang memiliki skor tertinggi yaitu BUM Desa jangkang sejahtera dengan skor 4,43, selanjutnya BUM Desa pasir bulan 3,65, dan BUM Desa Mulya Jaya Abadi dengan skor 3,05. Modal struktural menjadi yang saling bergantung dengan modal lainnya untuk melengkapi. Sehingga BUM Desa harus memiliki manajemen, inovasi yang saling mendukung di dalam internal BUM Desa tersebut. Menyediakan peluang bagi pengurus untuk memberikan inovasi-inovasi yang menarik dan dapat membantu meningkatkan BUM Desa menjadi lebih baik.

Kinerja keuangan adalah suatu analisis yang dilakukan untuk melihat sejauh mana suatu BUM Desa telah melaksanakan dengan menggunakan aturan-aturan pelaksanaan keuangan secara baik dan benar. Profitabilitas mengukur seberapa besar kemampuan BUM Desa dalam menghasilkan keuntungan. Rasio ini menggambarkan kemampuan BUM Desa mendapatkan laba melalui semua kemampuan dan sumber daya yang ada, seperti kegiatan penjualan, kas, modal, jumlah karyawan, jumlah cabang dan sebagainya. Selain itu rasio profitabilitas digunakan sebagai salah satu tolak ukur menilai kinerja manajemen dalam upaya menciptakan efisiensi dan efektifitas dalam menjalankan kegiatan operasionalnya. Sehingga rasio profitabilitas dapat diukur dengan Return on Asset (ROA), Return on Equity (ROE), dan Biaya Operasional Pendapatan Operasional (BOPO) diukur dengan laporan keuangan BUM Desa Kecamatan Bantan. Berikut laporan keuangan BUM Desa tahun 2019 di kecamatan Bantan dapat dilihat pada Tabel 5.

Tabel 5 Analisis Laporan Keuangan BUM Desa Kec. Bantan Tahun 2019

\begin{tabular}{|c|c|c|c|c|c|c|}
\hline No & $\begin{array}{l}\text { Nama BUM } \\
\text { Desa }\end{array}$ & $\begin{array}{l}\text { Laba Setelah Pajak } \\
\text { (Rp) }\end{array}$ & Total Aset (Rp) & Ekuitas (Rp) & $\begin{array}{c}\text { Biaya } \\
\text { Oprasional } \\
(\mathrm{Rp})\end{array}$ & $\begin{array}{c}\text { Pendapatan } \\
\text { Oprasional } \\
(\mathrm{Rp})\end{array}$ \\
\hline 1 & $\begin{array}{l}\text { Mulya Jaya } \\
\text { Abdi }\end{array}$ & 68,429 & $100,068,429$ & $100,000,000$ & 43,120 & 111,549 \\
\hline 2 & $\begin{array}{l}\text { Jangkang } \\
\text { Sejahtera }\end{array}$ & 29,010 & $4,328,367,952$ & $4,299,806,689$ & 12,253 & 41,263 \\
\hline 3 & Pasir Bulan & $2,628,548$ & $4,328,367,952$ & $661,253,853$ & 80,836 & $2,709,384$ \\
\hline
\end{tabular}

Sumber : Data Olahan 2020

Tabel 5 menunjukan bahwa laporan keuangan tahun 2019 masing-masing BUM Desa dengan laba setelah pajak, total asset, ekuitas, biaya operasional dan pendapatan operasional. Laba setelah pajak tertinggi yaitu BUM Desa Pasir Bulan yaitu sebesar Rp 2,628,548.total asset terbesar adalah BUM Desa Jangkang Sejahtera yaitu sebesar Rp $4,328,367,952$. Ekuitas terbesar yaitu BUM Desa Jangkang Sejahtera yaitu sebesar Rp
4,299,806,689. Biaya operasional terbesar adalah BUM Desa Pasir bulan dengan Rp 80,836. Pendapatan operasional tertinggi adalah BUM Desa Pasir Bulan yaitu sebesar Rp 2,709,384.

\section{Analisis Kinerja Keuangan}

BUM Desa adalah salah satu badan usaha berorientasi laba (profit) dimana laba tersebut bukan hanya untuk kepentingan pemilik, tetapi juga untuk pengembangan usaha. Menurut 
Kasmir (2010:92) rasio keuangan merupakan kegiatan membandingkan angka-angka yang ada dalam laporan keuangan dengan cara membagi satu angka dengan angka lainnya. Perbandingan dapat dilakukan antara satu komponen dengan komponen dalam satu laporan keuangan atau komponen yang ada di antara laporan keuangan. Kemudian angka yang diperbandingkan dapat berupa angka-angka dalam satu periode maupun beberapa periode.

1. Kinerja Keuangan BUM Desa berdasarkan return on assets

ROA (Return On Asset) adalah perbandingan rasio laba sebelum pajak (earning before tax) selama 12 bulan terakhir terhadap rata-rata volume usaha dalam periode yang sama. Rasio ini digunakan untuk mengukur kemampuan manajemen BUM Desa dalam memperoleh keuntungan (laba sebelum pajak) yang dihasilkan dari rata-rata total aset BUM Desa yang bersangkutan.Rasio ini digunakan untuk mengukur kemampuan manajemen BUM Desa dalam memperoleh keuntungan (laba) secara keseluruhan. Semakin besar ROA (Return On Asset) suatu BUM Desa, semakin besar pula tingkat keuntungan yang dicapai BUM Desa tersebut dan semakin baik pula posisi tersebut dari segi penggunaan aset. Analisis ROA bisa diproyeksikan ke masa depan untuk melihat BUM Desa dalam menghasilkan laba pada masa mendatang. Hasil perhitungan ROA BUM Desa Kecamatan Bantan selama 1 tahun 2019 pada Tabel 6.

Tabel 6 Perhitungan Return On Asset (ROA) BUM Desa Kecamatan Bantan Tahun 2019

\begin{tabular}{rlrrr}
\hline No & Nama BUM Desa & Laba Bersih (Rp) & \multicolumn{1}{c}{ Total Aset (Rp) } & Return On Asset (\%) \\
\hline 1 & Mulya Jaya Abadi & 111,549 & $100,068,429$ & $0,11 \%$ \\
2 & Jangkang Sejahtera & 41,263 & $4,328,367,952$ & $0,00 \%$ \\
3 & Pasir Bulan & $2,709,384$ & $663,852,047$ & $0,41 \%$ \\
\hline
\end{tabular}

Sumber: Data Olahan 2020

Berdasarkan Tabel 6 Return On Asset (roa) yang tertinggi adalah BUM Desa Pasir Bulan yaitu sebesar $0,41 \%$. Selanjutnya BUM Desa Mulia Jaya Abadi yaitu sebesar $0,11 \%$, dan BUM Desa Jangkang Sejahtera sebesar $0,00 \%$. ROA yang tertinggi yaitu BUM Desa Pasir Bulan yaitu $0,41 \%$ yang artinya setiap $R p$ 1, modal diinvestasikan dalam keseluruhan aktiva dapat menghasilkan keuntungan $\mathrm{Rp}$ 0,0554. Sehingga Semakin besar ROA (Return On Asset) suatu BUM Desa Berkah Bersama, semakin besar pula tingkat keuntungan yang dicapai BUM Desa Berkah Bersama tersebut dan semakin baik pula posisi tersebut dari segi penggunaan asset dan semakin besar pula tingkat keuntungan yang dicapai BUM Desa sehingga kemungkinan dalam kondisi bermasalah semakin kecil.

2. Kinerja keuangan BUM Desa berdasarkan return on equity (ROE)

Return On Equity (ROE) digunakan untuk mengukur kinerja manajemen BUM Desa dalam mengelola modal yang tersedia untuk menghasilkan laba setelah pajak. Semakin besar ROE, semakin besar pula tingkat keuntungan yang dicapai BUM Desa, sehingga kemungkinan dalam kondisi bermasalah semakin kecil. Perhitungan return on equity (ROE) BUM Desa Kecamatan Bantan tahun 2019 dapat dilihat pada Tabel 7.

Tabel 7 Perhitungan Return On Equity (ROE) BUM Desa Kecamatan Bantan Tahun 2019

\begin{tabular}{llrrr} 
No & Nama BUM Desa & Laba Bersih (Rp) & Ekuitas (Rp) & \multicolumn{1}{c}{ Return On Equity( \%) } \\
\hline 1 & Mulya Jaya Abadi & 68,429 & $100,000,000$ & $0,06 \%$ \\
2 & Jangkang Sejahtera & 29,010 & $4,299,806,689$ & $0,00 \%$ \\
3 & pasir Bulan & $2,628,548$ & $661,253,853$ & $0,39 \%$ \\
\hline
\end{tabular}

Sumber : Data olahan 2020

Berdasarkan Tabel 7 perhitungan return on equity (ROE) BUM Desa Kecamatan Bantan tahun 2019 yang tertinggi yaitu BUM Desa Pasir Bulan yaitu sebesar $0,39 \%$, selanjutnya BUM Desa Mulya jaya abadi yaitu 0,06\% dan BUM Desa Jangkang Sejahtera yaitu $0,00 \%$. Return on equity (ROE) yang tertinggi yaitu BUM Desa Pasir Bulan yaitu 0,39\% yang artinya sebesar 0,39\% menunjukan bahwa tingkat penghasilan yang diperoleh oleh BUM Desa atas modal yang diinvestasikan sebesar $0,39 \%$. Sedangkan ROE yang terendah yaitu BUM Desa Jangkang Sejahtera yang menandakan bahwa BUM Desa belum mampu mengelolah BUM Desa dengan baik.Nilai ini menunjukan kinerja keuangan dengan sampel 
BUM Desa cukup baik.

3. Kinerja keuangan BUM Desa berdasarkan Biaya Operasional Pendapatan Operasioal (BOPO)

BOPO (Biaya operasional terhadap pendapatan operasional) adalah perbandingan antara biaya operasional dan pendapatan operasional. Rasio ini digunakan untuk mengukur tingkat efisiensi dan kemampuan
BUM Desa dalam mengendalikan biaya operasional terhadap pendapatan operasionalnya. Persentase BOPO mencerminkan efisiensi perusahaan dalam kegiatan operasinya, semakin kecil persentase BOPO maka semakin efisien kinerja BUM Desa dalam melakukan operasinya. Perhitungan BOPO BUM Desa Kecamatan Bantan dalam periode 2019 pada Tabel 8 .

Tabel 8. Perhitungan Biaya Operaional dan Pendapatan OperasionalBUM Desa di Kecamatan Bantan Tahun 2019

\begin{tabular}{rlccc}
\hline No & Nama BUM Desa & Biaya Oprasional (Rp) & Pendapatan Oprasional (Rp) & BOPO (\%) \\
\hline 1 & Mulya Jaya Abadi & 43,120 & 111,549 & $38,66 \%$ \\
2 & Jangkang Sejahtera & 12,253 & 41,263 & $142,24 \%$ \\
3 & Pasir Bulan & 80,836 & $2,709,384$ & $103,07 \%$ \\
\hline
\end{tabular}

Sumber : Data Olahan 2020

Berdasarkan Tabel 8 perhitungan operaional dan pendapatan operasional BUM Desa di Kecamatan Bantan selama 1 tahun 2019 yang tertinggi adalah BUM Desa Jangkang Sejahtera yaitu sebesar $142,24 \%$, selanjutnya BUM Desa Pasir Bulan yaitu sebesar 103,07\% dan BUM Desa Mulya Jaya Abadi yaitu sebesar 38,66\%. Rasio BOPO tertinggi yaitu BUM Desa Jangkang Sejahtera yang menandakan bahwa belum efisiennya BUM Desa dalam menjalankan unit usaha yang dikembangkan.

4. Perbandingan Rasio-rasio Profitabilitas Profitabilitas mengukur seberapa besar kemampuan BUM Desa dalam menghasilkan keuntungan. Rasio ini menggambarkan kemampuan BUM Desa mendapatkan laba melalui semua kemampuan dan sumberdaya yang ada, seperti kegiatan penjualan, kas, modal, jumlah karyawan, jumlah cabang dan sebagainya. Selain itu rasio profitabilitas digunakan sebagai salah satu tolak ukur menilai kinerja manajemen dalam upaya menciptakan efisiensi dan efektifitas dalam menjalankan kegiatan operasionalnya. Profitabilitas dihitung dengan 3 rasio yaitu Return On Asset (ROA), Return On Equity (ROE), dan Biaya operasional terhadap pendapatan operasional (BOPO), sehingga dapat dilihat hasil perhitungan rasio profitabilitas BUM Desa Kecamatan Bantan pada Tabel 9.

Tabel 9 Hasil Perhitungan Rasio Profitabilitas BUM Desa Kecamatan Bantan Tahun 2019

\begin{tabular}{rlccc}
\hline No & Nama BUM Desaa & Return On Asset (\%) & Returrn On Equity (\%) & BOPO (\%) \\
\hline 1 & Mulya Jaya Abadi & $0,11 \%$ & $0,06 \%$ & $38,66 \%$ \\
2 & Jangkang Sejahtera & $0,00 \%$ & $0,00 \%$ & $142,24 \%$ \\
3 & Pasir Bulan & $0,41 \%$ & $0,39 \%$ & $103,07 \%$ \\
\hline
\end{tabular}

Sumber : Data Olahan 2020

Berdasarkan Tabel 9 hasil perhitungan rasio profitabilitas BUM Desa Kecamatan Bantan tahun 2019, pada ROA semakin besar ROA (Return On Asset) suatu BUM Desa, semakin besar pula tingkat keuntungan yang dicapai BUM Desa tersebut dan semakin baik pula posisi tersebut dari segi penggunaan asset dan semakin besar pula tingkat keuntungan yang dicapai BUM Desa sehingga kemungkinan dalam kondisi bermasalah semakin kecil. Rata-rata nilai ROA BUM Desa Kecamatan Bantan yaitu sebesar 142,24\% dengan kategori "sangat baik". Pada ROE semakin besar ROE, semakin besar pula tingkat keuntungan yang dicapai BUM Desa. Rata-rata
ROE BUM Desa yaitu 38,66 \% dengan kategori "kurang baik" yang berdasarkan surat edaran Bank Indonesia 6/23/DPNP/2011. Rasio BOPO memiliki rata-rata yaitu $142,24 \%$ yang dinilai "sangat baik".

\section{Hubungan Modal Intelektual Terhadap Kinerja Keuangan}

Analisis hubungan modal intelekual terhadap kinerja keuangan adalah dengan deskriptif, yang menjelaskan intelectual capital dengan rasio profitabilitas dari kinerja keuangan ROA, ROE, dan BOPO. Hubungan modal intelectual terhadap kinerja keuangan BUM Desa Kecamatan Bantan dapat dilihat pada Tabel 10. 
Tabel 10. Analisis Hubungan Modal Intelectual Terhdapat Kinerja Keuangan BUM Desa Kecamatan Bantan Tahun 2019

\begin{tabular}{|c|c|c|c|c|c|c|c|c|}
\hline \multirow[b]{2}{*}{ No } & \multirow[b]{2}{*}{ Nama BUM Desa } & \multicolumn{3}{|c|}{ Nilai Inteellectual Capital } & \multirow[b]{2}{*}{$\begin{array}{l}\text { Rata- } \\
\text { Rata }\end{array}$} & \multicolumn{3}{|c|}{ Kinerja Keuangan } \\
\hline & & $\begin{array}{l}\text { Human } \\
\text { Capital }\end{array}$ & $\begin{array}{c}\text { Relation } \\
\text { Capital }\end{array}$ & $\begin{array}{c}\text { Structural } \\
\text { Capital }\end{array}$ & & $\begin{array}{c}\text { Return } \\
\text { On } \\
\text { Asset }\end{array}$ & $\begin{array}{c}\text { Return } \\
\text { On } \\
\text { Equity }\end{array}$ & BOPO \\
\hline 1 & Mulya Jaya Abadi & 4,41 & 49,44 & 48,44 & 4,44 & 0,11 & 0,06 & 38,66 \\
\hline 2 & Jangkang Sejahtera & 37,59 & 32,08 & 29,93 & 3,90 & 0,00 & 0,00 & 142,24 \\
\hline 3 & Pasir Bulan & 27,23 & 27,18 & 25,73 & 3,26 & 0,41 & 0,39 & 103,07 \\
\hline
\end{tabular}

Sumber : Data Olahan 2020

Berdasarkan Tabel 10 menunjukan nilai intelectual capital dan kinerja keuangan. Intelectual capital terdapat human capital tertinggi ada pada BUM Desa Jangkang Sejahtera yaitu 37,59, selanjutnya BUM Desa Pasir Bulan yaitu 27,23, dan yang terendah adalah BUM Desa Mulya jaya abadi yaitu 4,41. BUM Desa dengan human capital tertinggi BUM Desa Jangkang sejahtera yaitu sebesar 37,59 yang memiliki kompetensi, kemampuan intelektual, kerjasama yang lebih baik dibandingkan BUM Desa lainya. Sedangkan untuk relational capital yang tertinggi BUM Desa mulya jaya abadi yaitu sebesar 49,44, selanjutnya BUM Desa Jangkang Sejahtera yaitu 32,08 dan BUM Desa dengan modal relasi paling rendah adalah BUM Desa Pasir Bulan yaitu 27,18. Modal relai tertinggi BUM Desa Mulya Jaya Abadi yang memiliki relasi yang baik antar pimpinan maupun pengurus serta kerjasama antar lembaga ataupun perusahaan sehingga lebih baik dibandingkan BUM Desa lainnya.

Structural capital yang tertinggi adalah BUM Desa Mulya jaya abdi yaitu sebesar 48,44, selanjutnya BUM Desa Jangkang Sejahtera yaitu sebesar 29,93, dan terakhir BUM Desa Pasir Bulan yaitu 25,73. Modal relasi atau Structural capital yang tertinggi yaitu BUM Desa Mulya Jaya abadi yang memiliki informasi yang baik, menguasai teknologi informasi, dan memiliki pengurus BUM Desa yang inovasi lebih baik dibandingkan dengan BUM Desa lainnya. Nilai rata-rata intelectual capital tertinggi yaitu BUM Desa Mulya jaya abadi dengan nilai 4,44 yang memiliki hubungan yang baik dari kompetensi, inovasi teknologi, relasi dengan pengurus dan kerjasama dengan badan usaha lainnya. BUM Desa Pasir Bulan mempunyai nilai ROA 0,41, yang menunjukan bahwa semakin besar ROA maka semakin besar pula keuntungan BUM Desaa dengan manajemen dan termasuk kategori "sangat baik". ROE yang dimiliki oleh BUM Desa pasir bulan yaitu 0,41 yang termasuk kategoti "kurang baik", dan BOPO BUM Desaa Mulya Jaya Abadi dengan nilai $38,66 \%$ yang menunjukan bahwa semakin kecil nilai BOPO maka semakin efesien kinerja BUM Desa dalam melakukan unit usaha dengan nilai terendah dari BUM Desa lainnya.

BUM Desa Mulya Jaya Abadi memiliki nilai intelectual capital yaitu 4,44 posisi pertama dari 3 BUM Desa. Nilai ROA BUM Desa Pasir Bulan yaitu 0,41 yang Tertinggi dari BUM Desa lainya dalam kategori "sangat baik". Nilai ROE BUM Desa jangkang sejahtera yaitu 0,00\% dengan kategori "kuran baik" dan nilai BOPO BUM Desa jangkang sejahtera yaitu sebesar 142,24\% yang tertinggi ke 2 dari BUM Desa lainya.

Intelectual Capital BUM Desa dengan nilai 3,26 yang terendah dari 3 BUM Desa yang mendaptkan perlu adanya inovasi dari unit usaha, relasi dengan pengurus perlu dibangun agar tercipta hubungan yang baik serta perlu adanya kerjama dengan badan usuaha lain untuk meningkatkan unit usaha di BUM Desa. ROA yang dimiliki oleh BUM Desa pasir bulan yaitu 0,41 yang tertinggi dari 3 BUM Desa lainya dengan kategori "sangat baik" dengan manajemen yang baik sehingga menghasilkan keuntungan yang banyak. ROE BUM Desa Pasir Bulan yaitu 0,39\% tertinggi dari BUM Desa lainnya, dengan kategori "cukup baik" dengan manajemen yang baik. BOPO BUM Desa jangkang sejahtera yaitu 142,24\% tertinggi dari BUM Desa lainya sehingga mampu memenejemen BUM Desa untuk mengelolah biaya operasional dengan kategori "sangat baik".

\section{KESIMPULAN}

Berdasarkaan hasil penelitian yang diuraiakan diatas, maka beberapa kesimpulan dari penelitian ini adalah: 
1. Ditemukan Intelectual capital dalam pengelolaan BUM Desa Kecamatan Bantan memiliki variabel tertinggi yaitu relational capital yang menunjukan sikap pengurus dan pimpinan BUM Desa yang saling membantu satu sama lain, mempunyai kerjasama yang baik dengan badan usaha untuk mengembangkan unit usaha dari BUM Desa. Sehingga menjadi point penting untuk meningkatkan keuntungan dari BUM Desa.

2. Kinerja keuangan BUM Desa Kecamatan Bantan tahun 2019 berdasakan ROA (Retrun On Asset) memiliki nilai rata rata $0,17 \%$ dengan kategori kurang baik. ROE (Retrun On Equity) memiliki nilai rata rata $0,15 \%$ dengan kategori kurang baik. Rasio BOPO (Biaya Oprasional dan Pendapatan Oprasional) yang memiliki nilai rata rata 94,65\% dengan kategori sangat baik.

3. Perolehan hasil penelitian ini dapat disimpulkan pula terdapat seselarasan dalam hasil penelitian yang dilakukan sebelumnya oleh Ayub (2020) bahwa Intelectual capital dan kinerja keuangan memiliki hubungan atau keterkaitan yang sangat seimbang. BUM Desa yang memiliki intelectual capital yang tinggi maka kinerja keuangannya juga baik. Intelectual capital yang memiliki nilai rendah maka kinerja keuanganya juga kurang baik. Sehingga intelectual capital memiliki hubungan yang signifikan dengan kinerja keuangan di Kecamatan Bantan.

\section{DAFTAR PUSTAKA}

Astuti, P.D. dan A.Sabeni. 2005. Hubungan Intellectual Capital and Business Performance. Prosiding SNA VII. Solo. pp. 694-707.

Bambang Presetyo dan Lina Miftahul Jannah. 2013. Metode Penelitian Kuantitatif: Teori dan Aplikasi. Jakarta: Rajawali Pers.

Barney, J.B. 1986. Strategic Factor Markets : Expectations, Luck and Bussines Strategy, Management Science, Vol. 32, pp. 1231-1241.

Chahal, Herdeep dan Purnima Bakshi. 2016. Measurement of Intelectual Capital in the Indian Banking Sector.Vol.41,pp.111

Cheng, Meng - Yuh, Jer - Yan Lin dan Tzy Yih Hsiao. 2010. Invested Resource,
Competitive Intellectual Capital and Corporate Performance. Journal of Intellectual Capital. Vol. 11, No. 4, pp. $433-450$.

Cholid Narbuko dan Abu Achmadi.(2013). Metodologi Penelitian.PT Bumi Aksara. Jakarta

Choong, K.K. (2008). Intellectual Capital: Definitions, Categorization and Reporting Models. Journal of Intellectual Capital, 9 (4), 609-638.

Deegan, C. 2004. Financial Accounting Theory. McGraw-Hill Book Company. Sydney.

Departemen Pendidikan Nasional, Pusat Kajian Dinamika Sistem Pembangunan. 2007. Panduan Pendirian dan Pengelolaan Badan Usaha Milik Desa. Universitas Brawijaya.

Dierickx, I. dan K. Cool. 1989. Asset Stock Acumulation and Sustainability of Competitive Advantage, Managament Science. Vol. 35, pp. $88-108$.

Edvinsson, L. and Malone, M.S. (1997). Intellectual Capital: Realizing Your Company's True Value by Finding Its Hidden Brainpower. Harper Business, New York, NY.

Ghozali dan Chariri, 2007. Teori Akuntansi. Badan Penerbit Undip. Semarang.

Ghutrie, R. Petty, F. Ferrier, and R. Well. 1999. "There is no accounting for intellectual capital in Australia: review of annual reporting practices and the internal measurement of intangibles within Australian organizations". Paper presented at the International Symposium Measuring and Reporting Intellectual Capital: Experiences, Issues and Prospects; OECD, June. Amsterdam.

Goh, P.C. 2005. Intellectual Capital Performance of Commercial Banks in Malaysia. Journal of Intellectual Capital, 6 (3), 385 - 396.

Grant, M. Robert. 1991. "The Resource Based Theory of Competitive Advantage : Implication for Strategy Simulation". California Management Review.

Imaningati.2007. Pengaruh Intellectual Capital terhadap Kinerja Perusahaan Real Estate \& Properti yang terdaftar di BEI tahun 2005 - 2006." Tesis, Undip. Semarang. 
Isna dan Sunaryo. 2012. Analisis Pengaruh Return On Asset, BOPO dan Suku Bunga terhadap Tingkat Bagi Hasil Deposito Mudharabah Pada Bank Umum Syariah, Jurnal Ekonomi dan Bisnis, Volume 11, Nomor 01, September 2012.

Kasmadi dan Nia Siti Sunariah.2014. Panduan Modern Penelitian Kuantitatif.Alfabeta. Bandung.

Machmud dan Rukmana. 2010. Bank Syariah. Erlangga. Jakarta.

Naphiet, Janine dan Sumantra Goshal. 1998. Social Capital, Intellectual Capital, and The Organizational Advantage. Academy of Managament Review Vol.23 No.242-266.

Pearce dan Robinson. 2008. Manajemen Strategis: Formulasi, Implementasi dan Pengendalian. Salemba Empat. Jakarta.

Peraturan Menteri Dalam Negeri Nomor 39 Tahun 2010 tentang Badan Usaha Milik Desa.

Peraturan Menteri Desa, Pembangunan Daerah Tertinggal, dan Transmigrasi Republik Indonesia Nomor 4 Tahun 2015 tentang pendirian, pengurusan, pengelolaan, dan pembubaran Badan Usaha Milik Desa.

Peraturan Pekon Gisting Bawah Nomor 1 Tahun 2015 tentang Pembentukan dan Pengelolaan Badan Usaha Milik Pekon (BUM-Pekon).

Peraturan Pemerintah Nomor 43 Tahun 2014 tentang Desa.
Purnomosidhi, Bambang. 2006. Praktik Pengungkapan Modal Intelektual padaperusahaan Publik di BEJ.Jurnal Riset Akuntansi Indonesia.Vol 9, No.1, $1-20$.

Pusat Kajian Dinamika Sistem Pembangunan (PKDSP). 2007. Buku Panduan Pendirian dan Pengelolaan Badan Usaha Milik Desa (BUM Desa).Fakultas Ekonomi Universitas Brawijaya. Malang.

Saleh, Norman Mohd, Rahman, Mara Ridhuan Abdul, dan Hasan. Mohamat Sabri. 2007. Ownership Structure and Intellectual Capital Performance in Malaysian Companies Listed in MESDAQ.www.ssrn.com.

Simarmata, Sona Monica. 2015. Pengaruh Intelectual Capital Terhadap Kinerja Keuangan Perusahaan BUMN Yang Terdaftar di Bursa Efek Indonesia Tahun 2009-2013. Skripsi.Universitas Negeri Semarang. Semarang.

Smedlund,AnssidandanAinoPoyhonen.2005."I ntellectualCapitalCreationinRegionsA KnowledgeSystemApproach".DalamB ounfourdanEdvinsson. Stewart,T.A.199 1."Brainpower",FortuneJune,page5355.

Sugiyono. 2004. Metode Penelitian BisnisI. Alfa Beta. Bandung.

Undang-Undang Nomor 5 Tahun 1974 tentang Pokok-pokok Pemerintahan di Daerah. Undang-Undang Nomor 5 Tahun 1979 tentang Pemerintahan Desa 
